\title{
Propagation of Atlantic White Cedar by Stem Cuttings
}

\author{
L. Eric Hinesley ${ }^{1}$, Frank A. Blazich ${ }^{1}$, and Layne K. Snelling ${ }^{2}$ \\ Department of Horticultural Science, North Carolina State University, Raleigh \\ NC 27695-7609
}

Additional index words. Chamaecyparis thyoides, Christmas trees, regeneration, rooting

Abstract. Hardwood and softwood stem cuttings of 5-year-old Atlantic white cedar [Chamaecyparis thyoides (L.) B.S.P.] were cut to 12-cm (short) or 24-cm (long) lengths, treated with 0 to $15 \mathrm{~g} \mathrm{IBA/liter} \mathrm{in} \mathrm{50 \%} \mathrm{isopropyl} \mathrm{alcohol,} \mathrm{and} \mathrm{rooted} \mathrm{in} \mathrm{a} \mathrm{raised} \mathrm{greenhouse}$ bench under intermittent mist. When hardwood cuttings were collected in February, short cuttings survived and rooted better than long cuttings. Survival and percent rooting for softwood cuttings collected in late August was virtually 10070 regardless of cutting length. Long cuttings produced more roots and longer roots with hardwood and softwood material. IBA was unnecessary for rooting, but it markedly increased the number of roots. Chemical name used: 1H-indole-3-butyric acid (IBA).

Atlantic white cedar, also known as southern white cedar or swamp cedar, grows in a narrow coastal belt from Mississippi to southern Maine (Korstian and Brush, 1931). It normally occurs on wet sites or in swamps near sea level, usually on very acidic peat (Little, 1950). Its distribution is scattered, owing to exacting site requirements, extreme sensitivity to tire, and the inability to compete on drier sites. The lightweight, rot-resistant wood of white cedar is used for boat construction, waterfowl decoys, and house siding. Natural stands are disappearing at an alarming rate as a consequence of logging, fire, drainage, and forest conversion. These events cause concern about the loss of genetic diversity. Atlantic white cedar has potential for wetlands reclamation and as an ornamental. Limited numbers have been planted for Christmas trees. In Christmas tree culture, a sheared white cedar resembles eastern red cedar (Juniperus virginiana L.), but has the advantage of soft foliage, compared to the prickly (awl-like) juvenile foliage of red cedar.

Little information is available concerning vegetative propagation of this species by stem cuttings. Dirr (1990) rated stem cuttings as somewhat difficult to root. Our objective was to examine rooting of stem cuttings in relation to cutting length, collection date, and IBA treatment.

\footnotetext{
Received for publication 19 Feb. 1993. Accepted for publication 19 Sept. 1993. This research was funded by the North Carolina Agricultural Research Service (NCARS), Raleigh, N.C. Use of trade names in this publication does not imply endorsement by the NCARS of products named nor criticism of similar ones not mentioned. We thank Ray Finch, who supplied the cuttings. The cost of publishing this paper was defrayed in part by the payment of page charges. Under postal regulations, this paper therefore must be hereby marked advertisement solely to indicate this fact.

'Professor.

${ }^{2}$ Research Technician.
}

\section{Materials and Methods}

Hardwood cuttings (Expt. 1). Stem cuttings were collected from a plantation of seedling Atlantic white cedar Christmas trees in Nash County, N. C., on 6 Feb. 1992. Trees were 5 years old, with heights of $\approx 2 \mathrm{~m}$. Eight terminal branch cuttings (tips of secondary axes) were taken from the middle crown of 50 trees. Four cuttings from each tree were kept in one group; four were placed in another group.

Cuttings were stored overnight in darkness at $\mathrm{SC}$ in polyethylene bags. The next day, the bases of cuttings from one group were trimmed to a length of $12 \mathrm{~cm}$; the other group to $24 \mathrm{~cm}$. Foliage was removed from the basal $4 \mathrm{~cm}$ of each cutting. Cuttings in each group were randomly assigned to four IBA treatments $(0$, $5.0,10.0$, or $15.0 \mathrm{~g} \cdot$ liter $\left.^{-1}\right)$. Reagent grade IBA was dissolved in 50\% isopropyl alcohol. The basal $2 \mathrm{~cm}$ of each cutting was dipped for 5 see, followed by $15 \mathrm{~min}$ air drying before insertion to a 4-cm depth in a raised greenhouse mist bed containing a nonheated medium of 1 Canadian peat: 1 perlite $(\mathrm{v} / \mathrm{v})$. Cuttings were spaced $\approx 4$ $\mathrm{cm}$ apart in the mist bed.

The design was a randomized complete block $(\mathrm{RCB})$ with four replications, eight treatments (two cutting lengths $\times$ four IBA concentrations), and 10 cuttings per plot. Day/night greenhouse cycles were $20 \pm 6 \mathrm{C} / 17 \pm 2 \mathrm{C}$. Intermittent mist was applied for $5 \mathrm{sec}$ every 5 min from 0700 to 1900 HR daily.

After 10 weeks, cuttings were evaluated for survival, percent rooting, number of roots, and length of the six longest roots. A cutting was considered rooted if it had at least one primary root $\geq 1 \mathrm{~mm}$ long. Average number of roots and average root length were based only on cuttings that rooted. If a cutting had fewer than six roots, the average root length was based on the number of roots present.

Percentages were transformed to arcsin and data subjected to analysis of variance. Where significant $(\mathrm{P} \leq 0.05)$ effects were indicated for IBA and cutting length, or their interaction, linear and quadratic effects were tested.
Softwood cuttings (Expt. 2). Softwood cuttings were collected from the same plantation on 26 Aug. 1992. Because most trees had been recently sheared, the collection protocol was changed. Sixty long $(\approx 30 \mathrm{~cm})$ and 60 short $(\approx 15 \mathrm{~cm})$ cuttings (tips of secondary axes) were taken from the middle crown of each of three nonsheared trees. Cuttings were segregated by length for each tree. An additional 120 cuttings were collected from six clumps of current-year stump sprouts, and thoroughly mixed. Cuttings were stored overnight at $5 \mathrm{C}$.

On 27 Aug. 1992, the bases of long and short cuttings were trimmed to final lengths of 12 and $24 \mathrm{~cm}$, respectively. Cuttings from stump sprouts were divided into two groups and also cut to $12-$ and $24-\mathrm{cm}$ lengths. Foliage was removed from the basal third of each cutting. Five concentrations of IBA $(0,2.0$, 5.0, 7.5, or $10.0 \mathrm{~g} \cdot$ liter $\left.^{-1}\right)$ were prepared as described previously and applied to the basal $2 \mathrm{~cm}$ of cuttings. Cuttings were inserted $4 \mathrm{~cm}$ into the rooting medium.

Cuttings were rooted with the same medium and in the same mist bed as in Expt. 1, using a RCB design with six replications, 10 treatments (two cutting lengths $\times$ five IBA concentrations), and eight cuttings per plot. Each plot contained two cuttings from each of the three nonsheared trees and two cuttings from the stump sprouts. Day/night greenhouse cycles were $23 \pm 7 \mathrm{C} / 20 \pm 4 \mathrm{C}$, and intermittent mist was applied as in Expt. 1.

Survival and percent rooting were recorded after 11 weeks in the mist bed. Data from each rooted cutting included the number of roots $\geq 1$ $\mathrm{mm}$ long and length of the six longest roots. Data were analyzed as in Expt. 1. Significance tests in both experiments were at $P \leq 0.05$ and 0.01 .

\section{Results}

Hardwood cuttings (Expt 1). Survival (transformed data) was significantly affected by cutting length (Table 1); the mean for short (12-cm) cuttings was $90 \%$, compared to $78 \%$ for long $(24-\mathrm{cm})$ cuttings (Table 2). There was no discernible relationship between survival and IBA concentration (Table 2).

Percent rooting over all IBA treatments was $58 \%$ to $69 \%$ (Table 2). Percent rooting was only affected by cutting length (Table 1), with short cuttings averaging $83 \%$ and long cuttings half as much (Table 2).

Table 1. Analyses of variance for rooting response of Atlantic white cedar stem cuttings.

\begin{tabular}{|c|c|c|c|c|}
\hline Source ${ }^{z}$ & $\begin{array}{c}\text { Survival } \\
(\%)\end{array}$ & $\begin{array}{c}\text { Rooting } \\
(\%)\end{array}$ & $\begin{array}{c}\text { Root } \\
\text { no. }\end{array}$ & $\begin{array}{l}\text { Root length } \\
(\mathrm{mm})\end{array}$ \\
\hline \multicolumn{5}{|c|}{ Hardwood cuttings (Expt. 1) } \\
\hline IBA & NS & NS & $* *$ & $* *$ \\
\hline $\mathrm{L}$ & * & $* *$ & $* *$ & $* *$ \\
\hline $\mathrm{IBA} \times \mathrm{L}$ & NS & NS & $*$ & NS \\
\hline \multicolumn{5}{|c|}{ Softwood cuttings (Expt. 2) } \\
\hline IBA & NS & NS & $* *$ & $*$ \\
\hline $\mathrm{L}$ & NS & NS & $* *$ & $* *$ \\
\hline $\mathrm{IBA} \times \mathrm{L}$ & NS & NS & NS & NS \\
\hline
\end{tabular}


Table 2. Rooting response of hardwood stem cuttings of Atlantic white cedar collected in February (Expt. 1).

\begin{tabular}{lccc}
\hline Treatment & $\begin{array}{c}\text { Survival } \\
(\%)\end{array}$ & $\begin{array}{c}\text { Rooting } \\
(\%)\end{array}$ & $\begin{array}{c}\text { Root length }^{2} \\
(\mathrm{~mm})\end{array}$ \\
\hline IBA $\left(\mathrm{g} \cdot \mathrm{liter}^{-1}\right)$ & & & \\
0 & 91.2 & 68.8 & 63 \\
5.0 & 82.5 & 61.2 & 67 \\
10.0 & 83.8 & 58.8 & 56 \\
15.0 & 77.5 & 57.5 & 54 \\
Linear & $\mathrm{NS}$ & $\mathrm{NS}$ & $*$ \\
Quadratic & $\mathrm{NS}$ & $\mathrm{NS}$ & $\mathrm{NS}$ \\
Length & & & \\
$\quad$ Short & 90.0 & 82.5 & 54 \\
& $* *$ & $* *$ & $* *$ \\
Long & 77.5 & 40.6 & 67 \\
\hline \hline
\end{tabular}

${ }^{2}$ Length of six longest roots.

ss $*, * *$ Nonsignificant or significant at $\mathrm{P} \leq 0.05$ or 0.01 , respectively.

The number of roots (Fig. 1) was affected by cutting length and IBA concentration (Table 1). The number of roots on long cuttings increased linearly $(r=0.69)$ from 15 in nontreated controls to $\approx 40$ roots per cutting at 10.0 and 15.0 g IBA/liter (Fig. 1). Root count in short cuttings also increased linearly $(r=$ 0.70 ) from eight in nontreated controls to 15 at the highest IBA concentration ( $15.0 \mathrm{~g} \cdot$ liter $^{-1}$ ).

Root length also was affected by cutting length and IBA concentration (Table 1). For long cuttings, the six longest roots averaged 67 $\mathrm{mm}$, vs. $55 \mathrm{~mm}$ in short cuttings (Table 2). The average length of the six longest roots decreased linearly $(r=0.33)$ from 63 rum in nontreated controls to $54 \mathrm{~mm}$ at $15.0 \mathrm{~g} \mathrm{IBA} /$ liter (Table 2).

Softwood cuttings (Expt. 2). Percent survival and percent rooting were not affected by IBA or cutting length (Table 1). Only three of the 480 cuttings died, and every surviving cutting produced roots.

The number of roots per rooted cutting was strongly affected by cutting length (Table 1 ); long cuttings averaged 15 roots, compared to

HARDWOOD CUTTINGS (EXPT. 1)

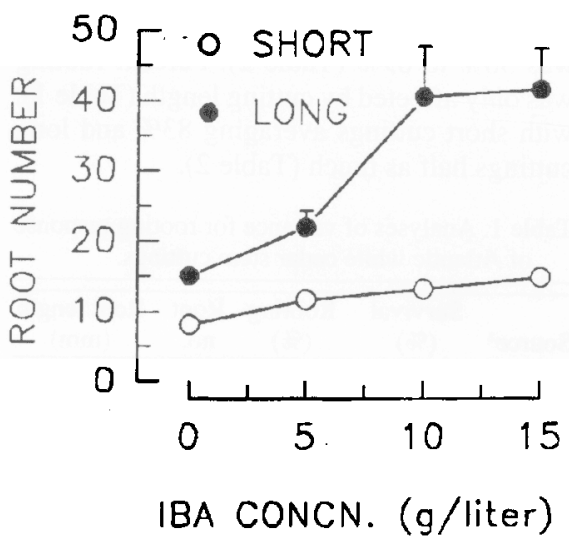

Fig. 1. Average number of roots per rooted cutting (10-week rooting period) for hardwood stem cuttings of Atlantic white cedar in relation to cutting length and IBA treatment (Expt. 1). Vertical bars $=\mathrm{SE}$.
Table 3. Rooting response of softwood stem cuttings of Atlantic white cedar collected in August (Expt. 2).

\begin{tabular}{lcc}
\hline \hline Treatment & Root count & $\begin{array}{c}\text { Root length } \\
(\mathrm{mm})\end{array}$ \\
\hline IBA $\left(\mathrm{g} \cdot\right.$ liter $\left.^{-1}\right)$ & & \\
0 & 8.5 & 109 \\
2.5 & 11.6 & 103 \\
5.0 & 11.1 & 106 \\
7.5 & 11.8 & 106 \\
10.0 & 12.0 & 95 \\
Linear & $\mathrm{NS}$ & $\mathrm{NS}$ \\
Quadratic & $\mathrm{NS}$ & $\mathrm{NS}$ \\
Length & & \\
Short & 7.4 & 89.9 \\
& $* *$ & $* *$ \\
Long & 14.6 & 117.4 \\
\hline
\end{tabular}

${ }^{2}$ Length of six longest roots.

, ${ }^{\text {Ns }}$ Nonsignificant or significant at $P \leq 0.01$, respectively.

half as many for short cuttings (Table 3). Cuttings not treated with IBA averaged nine roots, compared to 11 to 12 roots for those treated with IBA (Table 3 ).

Root length also varied by cutting length, averaging $117 \mathrm{~mm}$ in long cuttings, 30\% longer than in short cuttings (Table 3). The main effect for IBA was significant (Table 1), but there was no discernible relationship between IBA concentration and root length (Table 3 ). Average length of the six longest roots was 106 to $109 \mathrm{~mm}$, except at $10.0 \mathrm{~g}$ IBA/liter where it was 95 nun.

\section{Discussion}

Although these experiments were conducted in different seasons and with somewhat different methodology, several conclusions are warranted. First, a high percentage of stem cuttings (softwood or hardwood) of juvenile Atlantic white cedar rooted. Good rooting potential has also been reported in other species of Chamaecyparis Spach and related cultivars (Dirr and Heuser, 1987; Hartmann et al., 1990). Because cuttings in both experiments were from young trees, the extent to which rooting capacity, or the responsiveness to IBA, changes with stock plant maturity is unknown.

Whether short $(12-\mathrm{cm})$ or long $(24-\mathrm{cm})$ cuttings are best is unclear, although results were satisfactory with both. Survival and percent rooting of hardwood material collected in February was best with short cuttings (Expt. 1, Table 2), whereas in Expt. 2, which used softwood material, virtually all cuttings survived and rooted regardless of length. However, in both experiments, root development (number, length) was best with long cuttings (Tables 2 and 3).

Root development (number, length) was satisfactory, even without IBA treatment. The index that positively responded to IBA in both experiments was root count, especially with 24-cm hardwood cuttings (Fig. 1, Table 3).

Atlantic white cedar stem cuttings produced many adventitious roots; root systems

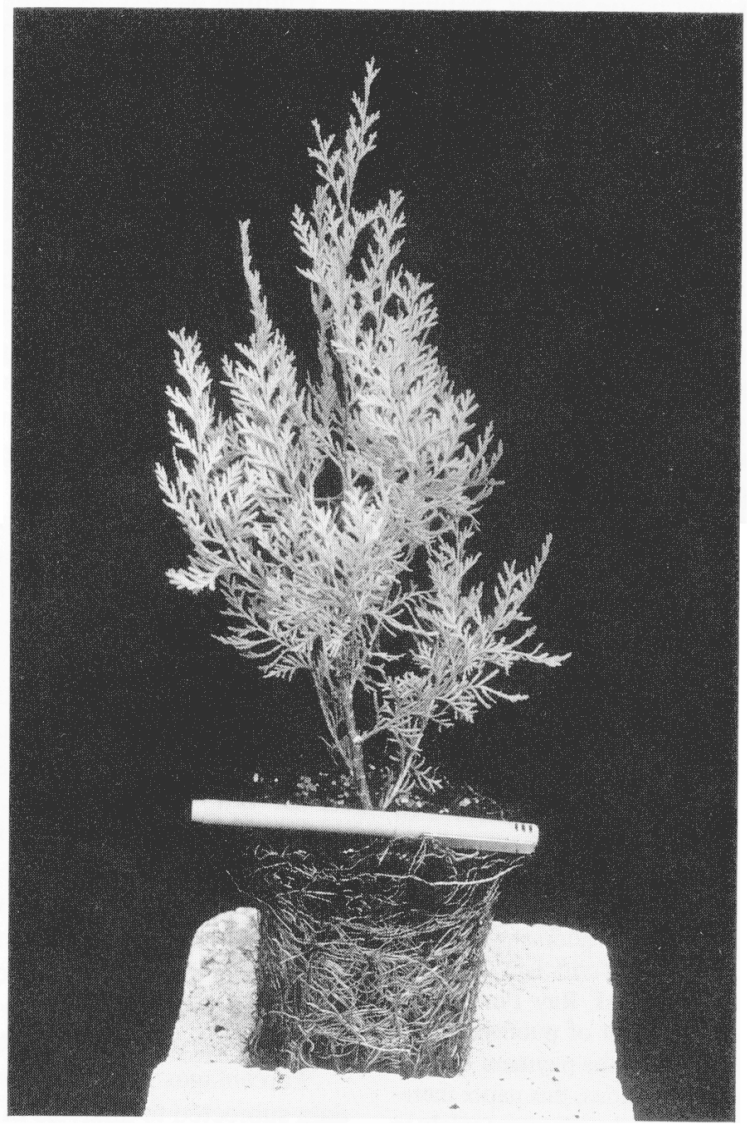

Fig. 2. Transplant of Atlantic white cedar originating from a stem cutting rooted in Expt. 2. This plant grew outdoors in a 1-liter container during the 1993 growing season. A writing penis on the root ball. 
were symmetrical and well balanced. Roots were evenly distributed around the perimeter and emerged in a zone several centimeters wide, not just at the cut basal portion. This type of root development should produce strong plants that are unlikely to be uprooted. Rooted cuttings made good-quality transplants by the end of the first growing season in pots (Fig. 2).

Some conifers propagate easily from stem cuttings, but have the habit of plagiotropic growth (like a branch) for months or years afterwards. New vegetative growth on rooted stem cuttings of Atlantic white cedar was orthotropic.
We suggest propagation of Atlantic white cedar with softwood stem cuttings collected in August; virtually all of these cuttings survived and rooted well, even without IBA treatment. However, hardwood cuttings also rooted well (83\% rooting for short cuttings, Table 2). IBA increased the number of roots, and root development was best for long cuttings.

\section{Literature Cited}

Dirr, M.A. 1990. Manual of woody landscape plants: Their identification, ornamental characteristics, culture, propagation and uses. 4th ed. Stipes publishing Co., Champaign, Ill.
Dirr, M.A. and C.W. Heuser, Jr. 1987. The reference manual of woody plant propagation: From seed to tissue culture. Varsity Press, Athens, Ga.

Hartmann, H.T., D.E. Kester, and F.T. Davis, Jr. 1990. Plant propagation: Principles and practices. 5th ed. Prentice-Hall, Englewood Cliffs, N.J.

Korstian, C.F. and W.D. Brush. 1931. Southern white cedar. U.S. Dept. Agr. For. Serv. Tech. Bul. 251.

Little, S. 1950. Ecology and silviculture of white cedar and associated hardwoods in southern New Jersey. Yale Univ. School For. Bul. 56. New Haven, Corm. 